\title{
PENGARUH KEPEMIMPINAN KHARISMATIK KYAI DAN MOTIVASI ORANG TUA TERHADAP ETOS BELAJAR SANTRI STUDI KASUS ATAS PONDOK PESANTREN 'AINURRAFIQ KUNINGAN
}

\author{
Asep Kurniawan \\ Staf pengajar Institut Agama Islam Negeri Syekh Nurjati Cirebon \\ asepqurniawan.ak@gmail.com
}

\begin{abstract}
Abstrak
Penelitian ini bertujuan untuk mengungkap lebih jauh tentang pengaruh kepemimpinan kharismatik kyai dan motivasi orang tua terhadap etos belajar santri: Studi kasus atas Pondok Pesantren 'Ainurrafiq Kuningan. Metode penelitian adalah kuantitatif korelasional. Sampel berjumlah 29 santri dari populasi 150 santri. Instrumen pengumpulan data menggunakan angket, observasi dan dokumentasi. (1) Kepemimpinan kharismatik kyai mempunyai pengaruh yang signifikan terhadap etos belajar santri. (2) Motivasi orang tua mempunyai pengaruh yang signifikan terhadap etos belajar santri. (3) Kepemimpinan kharismatik kyai dan motivasi orang tua secara bersama-sama mempunyai pengaruh yang signifikan terhadap etos belajar santri. Temuan ini berimplikasi bahwa (1) semakin besar pengaruh kepemimpinan kharismatik kyai, maka akan semakin tinggi pula etos belajar santri. (2) Semakin besar pengaruh motivasi orang tua, maka akan semakin tinggi pula etos belajar santri. (3) Semakin besar pengaruh kepemimpinan kharismatik kyai dan motivasi orang tua, maka akan semakin tinggi pula etos belajar santri.
\end{abstract}

Kata Kunci: keteladanan, peniruan, perubahan hasil belajar

\section{A. Latar Belakang Masalah}

Lembaga pendidikan yang terkenal dan banyak dijumpai saat ini adalah lembagapendidikan sekolah formal di bawah naungan kementrian pendidikan nasional seperti sekolah dasar, sekolah menengah pertama dan sekolah menengah atas. Sedangkan lembaga pendidkan di bawah naungan kementerian agama yang formal hanya sedikit jumlahnya, seperti madrasah ibtidaiyah, madrasah tsanawiyah dan madrasah aliyah. Selain yang formal yang ada di bawah naungan kementerian agama, ada juga lembaga pendidikan non formal seperti lembaga pendidikan pesantren.

Pada saat ini pesantren dikenal dengan dua tipe pesantren, yaitu pesantren salafy dan pesantren modern. Yang membedakan kedua pesantren tersebut diantaranya adalah materi yang di berikan dan metode yang digunakan. Pesantren salafy materinya hampir semua tentang masalah agama dengan menggunakan kitab kuning dan metode pembelajaran yang klasik seperti sorogan dan pasaran. Sedangkan pesantren modern selain materi masalah agama juga memberikan materi pelajaran umum dengan metode pengajaran yang modern sesuai dengan model model pembelajaran di sekolah formal.

Semua lembaga pendidikan memiliki tanggungjawab untuk mewujudkan pendidikan yang berkualitas, begitu pula lembaga pendidikan Islam, yang sekaligus bagian Integral dari sistem pendidikan Nasional di Negara ini. Pendidikan dan Asep Kurniawan Vol. 2 No.2 ISSN 2549-0877 
pengajaran adalah suatu proses yang sadar akan tujuan, maksudnya tidak lain bahwa kegiatan belajar mengajar merupakan suatu peristiwa yang terikat, terarah pada tujuan dan dilaksanakan untuk mencapai tujuan (Sardiman, 2016: 57). Tujuan pendidikan menekankan nilai kepada individu, menekankan potensinya untuk secara positif mempengaruhi perkembangan pribadi siswa, mempromosikan otonomi, membentuk identitas budaya atau membangun karir atau pekerjaan. Pandangan lain menekankan kontribusi pendidikan untuk tujuan kemasyarakatan, termasuk kewarganegaraan yang baik, membentuk siswa menjadi anggota masyarakat yang produktif, dengan demikian mendorong perkembangan ekonomi masyarakat secara umum, dan melestarikan nilai-nilai budaya (Winch \& Gingell, 2008: 10-11).

Pendidikan dan pengajaran merupakan dua hal yang tidak bisa dipisahkan dalam suatau proses pendidikan. Lembaga pendidikan tidak hanya melakukan pengajaran dengan cara mentransfer ilmu pengetahuan kepada para siswa, melainkan juga harus mampu mendidik para siswa dengan mengamalkan dan mempraktekan nilai-nilai pendidikan karakter yang ada pada setiap mata pelajaran yang disampaikan. Dalam kegiatan belajar mengajar akan berhasil baik kalau siswa tekun dan mengerjakan tugas, ulet dalam memecahkan berbagai masalah dan hambatan secara mandiri. Siswa yang belajar dengan baik tidak akan terjebak pada suatu yang rutinitas dan mekanis (Sardiman, 2016: 84).

Dalam dunia pendidikan bukan hanya lembaga pendidikan saja yang berperan penting, tetapi keluarga juga mempunyai peranan dan tanggungjawab yang penting atas perawatan anak sejak dini sampai remaja. Pengenalan anak kepada kebudayaan, pendidikan, nilai norma-norma kehidupan masyarakat dimulai dari lingkungan keluarga. Oleh karena itu komunikasi yang baik antara orang tua dengan anak mempunyai peran penting dalam membina hubungan keduanya, hal ini dapat dilihat ketika orang tua membimbing, membantu mengarahkan, menasehati dan memberikan motivasi. Orang tua yang jarang memberikan motivasi dengan berkomunikasi terhadap anaknya akan menimbulkan kerenggangan hubungan, sebaliknya orang tua yang sering berkomunikasi dengan memberikan motivasi kepada anaknya, maka anak tersebut cenderung dapat berkembang, menumbuhkan semangat belajar, kreatif, dan inovatif.

Motivasi adalah arah seseorang terhadap perilaku, atau apa yang menyebabkan seseorang ingin mengulangi perilaku, seperangkat kekuatan yang bertindak di belakang motif (Ryan dan Deci, 2000: 68). Motivasi di balik semua perilaku adalah keinginan untuk diberi peranan, untuk diterima dalam keluarga dan untuk dapat memainkan fungsi yang konstruktif mereka memiliki sikap yang terlalu ambisius, harapan yang negatif membanding bandingkan dengan teman yang sebaya, telah menaruh perhatian kepada kedudukan, terlalu terpaku kepada pendekatan dan peneriman remaja dengan bersyarat atau tidak menerima apa adanya (Balson, 1996: 152).

Diantara salah satu harapan orang tua dalam mendidik anaknya (mengubah perilaku anak) adalah adanya perubahan perilaku anaknya ke arah yang lebih baik dan berakhlak terpuji serta hidupnya di masa yang akan datang sukses dan bahagia. Orang tua jangan membebani pikiran anaknya agar kelak menjadi seperti seseorang yang diharapkan orang tuanya. Tetapi orang tua harus memberi motivasi kepada anknya agar rajin dan nyaman dalam belajar. Jika anknya ketika berada di rumah malas belajar, Para orang tua biasanya melaporkan anaknya kepada gurunya (Kyai) bahwa anaknya kurang semangat belajarnya ketika berada di rumah, padahal anak-anak tersebut 
sebenarnya menaruh perhatian besar kepada orang tuanya, yang justru meragukan kemampuan orang tuanya yang jarang memberi motivasi kepada anaknya, sehingga mempengaruhi anaknya dan merasa kecewa terhadap masa depan mereka. Orang tua merupakan sumber utama pemberi semangat, walaupun keinginan anaknya kadang-kadang tidak sejalan dengan pemikiran orang tua tersebut. Membantu anak agar memiliki kepercayaan kepada diri sendiri menjadi tugas dan kewajiban orang tua.

Beberapa bulan kebelakang tepatnya tanggal 13Juni 2018 penulis melakukan penelitian awal di Pondok Pesantren 'Ainurrafiq Kuningan Jl. Pemuda No. 001 RT 007 RW 003, Desa Panawuan, Kecamatan Cigandamekar, Kabupaten Kuningan, Jawa Barat, penulis menemukan beberapa hal kejadian yang terjadi di pesantren tersebut. Kejadian pertama penulis merasa kaget ketika melihat para santri banyak yang baru tiba untuk sholat jum'at ke mesjid jami kampung tersebut hanya beberapa menit lagi ke waktu sholat jum'at, bahkan ada sebagian yang tiba ketika adzan shalat jum'at. Padahal seyogyanya mereka berangkat shalat jum'at lebih awal tidak mendekati masuknya awal waktu sholat jum'at dan terlambat. Kenapa mereka seperti itu, karena setiap kyai memiliki kharismatik tersendiri dalam mengendalikan santrinya. Dikalangan santri dikenal dengan istilah prinsip sami'na wa ato'na (mendengar perkataannnya dan melaksanakan perintahnya). Kejadian itu menunjukan adanya ketimpangan. seyogyanya kharismatik yang dimiliki kyai mampu mengendalikan kedisiplinan santri terhadap waktu sholat jum'at. Hal inilah yang mendorong peneliti ingin mengetahui seberapa besar pengaruhnya kadar kharismatik kyai terhadap santri dalam mengendalikan santri dan pengelolaan pendidikan di pesantren tersebut.
Kejadian ke dua, penulis merasa kaget ketika para santri masih banyak yang terlambat datang masuk ruang kelas / madrasah pada saat kegiatan belajar mengajar sudah dimulai, Padahal seyogyanya mereka masuk ruang kelas / madrasah lebih awal sebelum kegiatan pengajian dimulai. Kebutuhan yang mereka perlukan dalam belajar sudah dipenuhi orang tua, Kenapa etos belajar mereka seperti itu. Disini juga terdapat ketimpangan, seharusnya ketika kebutuhan santri dipenuhi oleh orang tuanya, etos belajrnya meningkat. Hal ini yang mendorong penulis untuk mengetahui seberapa besar kadar pengaruh motivasi otang tua dalam bentuk perhatian yang selama ini diberikan terhadap anaknya dan pemenuhan kebutuhan biaya hidaup di pesantren terhadap etos belajar anaknya.

Orang yang beruntung dirinya adalah orang yang memperoleh kesempatan untuk mendalami agama. Mereka mendapat kedudukan yang tinggi di sisi Allah dan tidak kalah tingginya dari kalangan pejuang yang mengorbankan harta dan jiwa dalam meninggikan kalimat Allah, membela agama dan ajarannya. Bahkan mereka boleh jadi lebih utama dari para pejuang pada selain situasi ketika mempertahankan agama menjadi wajib 'ain bagi setiap orang. Semua manusia dilahirakn tidak memiliki ilmu pengetahuan sedikitpun, oleh karena itu untuk bisa hidup agar tidak sengsara didunia, manusia harus belajar ilmu pengetahuan yang dibutuhkan yang belum diketahuinya. Hal itu sesuai dengan firman Allah di bawah ini "Dia (Allah) mengajarkan kepada manusia apa yang tidak belum diketahuinya (al-Qur'an Surat al-'Alaq ayat 5).

Penjelasan ayat al-Qur'an di atas, bahwa sesungguhnya Dzat Yang memerintahkan kita belajar ilmu pengetahuan yang belum kita ketahui adalah Allah, Allah yang mengajarkan berbagai ilmu yang dinikmati oleh umat manusia, sehingga manusia berbeda dari 
makhluk lainnya. Pada mulanya manusia itu bodoh, manusia tidak mengetahui apaapa. Begitu pula santri belajar di pondok pesantren menyadari bahwa dirinya tidak tahu apa-apa tentang ilmu pengetahuan agama, makanya santri belajar di pondok pesantren kepada para kyai. Ayat ini merupakan dalil yang menunjukkan tentang motivasi belajar, baik belajar melalui membaca, menulis dalam mendapatkan ilmu pengetahuan.

Berdasarkan fakta tersebut di atas, maka penulis tertarik untuk melakukan penelitian kenapa bisa terjadi seperti itu. Karena kepemimpinan kharismatik kyai dan motivasi orang tua memiliki pengaruh terhadap etos belajar santri, hanya saja sebearapa besar kharismatik kyai di pesantren itu dan seberapa besar pengaruh motivasi orang tua dapat menumbuhkan dan meningkatkan semangat belajar santri di pondok pesantren tersebut. Hal itu memiliki kemiripan dengan penelitian Pengaruh Gaya Kepemimpinan dan Motivasi Kerja Terhadap Kinerja Guru di SMPN 1 Pandan Kabupaten Tapanuli Tengah (Absah, 2014: 4),Effect of leadership styles on teacher's performance in primary schools of Arusha District Tanzania (Aunga1 and Masare1, 2017), dan Leadership Style and Teacher Work Motivation Empiricirical Investigation from Secondary Shools in Mogadishu Somalia (Dahie, Mohamed, dan Jim'ale, 2015: 276-292) yang mana gaya kepemimpinan dan motivasi kerja berpengaruh positif dan signifikan terahadap kinerja guru. Hal itulah yang menjadi latar belakang masalah penelitian ini yang mendasari penulis ingin melakukan penelitian di pesantren tersebut.

Karena masalah tersebut, maka penulis disini sangat tertarik meneliti seberapa besar pengaruh kharismatik kyai sebagai guru dan pembimbing ketika di pesantren dan seberapa besar pengaruh motivasi orang tua terhadap etos belajar santri dalam sebuah pondok pesantren yang ada di wilayah kabupaten Kuningan. Oleh karena itu penulis memberikan judul dalam penelitian ini yaitu pengaruh kepemimpinan kharismatik kyai dan motivasi orang tua terhadap etos belajar santri: Studi kasus Atas Pondok Pesantren 'Ainurrafiq Kuningan Jawa Barat.

\section{A. Landasan Teori}

1. Teori antar kepemimpinan kharismatik kyai dengan etos belajar santri

Pemimpin kharismatik esensinya adalah pemimpin transpormasi. Dalam teori Max Weber, kepemimpinan seperti ini menggunakan pesona atau daya tarik pribadi dan kharisma dalam menjalankan roda kepemimpinannya untuk membantu mereka dalam mencapai tujuannya (Danim, 2010: 93). Oleh karena itu, pada perkembangan berikutnya, kepemimpinan transformasional memiliki idealisasi pengaruh (Idealized Influence). Idealisasi pengaruh adalah perilaku yang menghasilkan standar perilaku yang tinggi, memberikan wawasan dan kesadaran akan visi, menunjukkan keyakinan, menimbulkan rasa hormat, bangga dan percaya, menumbuhkan komitmen dan unjuk kerja melebihi ekspektasi, dan menegakkan perilaku moral yang etis (Avolio, Bass, Jung, 1999: 441-462). Max Weber mengambil gagasan teologis untuk digunakan pada konteks agama (Joosse, 2014: 266-283). Istilah lain yang digunakan adalah "dominasi karismatik" (Weber, 1978: 92-94), dan "kepemimpinan karismatik" (AdairToteff, 2005: 189-204).

Dalam teori muhaimin, Etos adalah kebiasaan, adat istiadat, atau juga kecenderungan moral, pandangan hidup yang dimiliki oleh seseorang, suatu golongan suatu bangsa (Muhaimin. 2012: 112). Kebiasaan yang dilakukan santri di pondok pesantren merupakan kegiatan yang biasa dan terbiasa. Maka 
kecenderungan melakukan suatu kebiasaan yang rutin dilakukan tersebut dapat di katakan sebagai etos santri. Berdasarkan kutipan di atas terdapat hubungan teori antara kepemimpian kharismatik kyai dengan etos belajar santri, yaitu:

a. Idealisme pengaruh kharismatik kyai terhadap etos belajar dapat menghasilkan standar prilaku santri yang tinggi.

Pemimpin yang memiliki
idealisasi menunjukkan perilaku yang tinggi yang dapat mempengaruhi etos belajar santri sebagai bawahannya. Santri sebagai bawahan didalam lembaga pondok pesantren akan senantiasa menunjukan prilaku yang dipengaruhi oleh kyai sebagai pemimpin yang punya Pengaruh kharismatik didalam kehidupan lingkungan pesantren. Santri selalu belajar dari ekspresi yang terpancar dari kharismatik kyai. Belajar adalah tingkah laku yang dihasilkan dari rangsangan (Mustakim, 2012: 33). Kyai tersebut dapat menghasilkan standar prilaku yang tinggi. membuat bawahan berusaha meniru perilaku dan mengidentifikasi diri dengan pemimpinnya, menginspirasikan bawahan untuk menerima nilai-nilai, norma-norma, dan prinsip-prinsip bersama, mengembangkan visi bersama, menginspirasikan bawahan untuk mewujudkan standar perilaku secara konsisten, mengembangkan budaya dan ideologi organisasi yang sejalan dengan masyarakat pada umumnya, dan menunjukkan rasa tanggung jawab sosial dan jiwa melayani yang sejati.

b. Idealisme pengaruh kharismatik kyai dapat memberikan wawasan dan kesadaran santri dalam belajar

Dalam usaha pencapaian tujuan belajar perlu diciptakan adanya sistem lingkungan belajar yang lebih kondusif. Mengenai tujuan belajar sebenarnya sangat banyak dan bervariasi jumlahnya. Menurut Sardiman ditinjau secara umum, maka tujuan belajar diantarnya untuk Mendapatkan Pengetahuan. Hal ini ditandai dengan kemampuan berfikir, memiliki pengetahuan dan kemampuan berfikir tidak bisa dipisahkan, dengan kata lain tidak dapat mengembangkan kemampuan berfikir tanpa bahan pengetahuan, sebaliknya kemampuan berfikir akan memperkaya (Sardiman, 2016: 26).

2. Teori antar motivasi orang tua dengan etos belajar santri

Dalam teori Mc. Donald dalam Sardiman, bahwa motivasi adalah perubahan energi dalam diri seseorang yang ditandai dengan munculnya "feeling" dan didahului dengan tanggapan terhadap adanya tujuan (Sardiman, 2016: 73). Dalam kegiatan belajar mengajar, apabila ada siswa yang tidak berbuat sesuatu yang seharusnya mereka lakukan, maka perlu adanya penelitian penyebab hal tersebut. Hal itu berarti pada diri anak tersebut tidak terdapat energi positif / dorongan untuk memiliki etos belajar yang baik. Energi positif tersebut dapat berupa motovasi orang tua untuk mendorong anknya bersemangat dalam belajar, dengan menasehati, memberikan rangsangan mendapatkan hadiah dan memberikan penjelasan manfaat hasil belajar bagi kehidupan masa depan.

Dengan demikian, motivasi merupakan dorongan atau rangsangan yang timbul dari dalam jiwa manusia baik berupa tindakan / action maupun sikap yang lebih baik dan agresif. Dorongan tersebut mengarah pada sesuatu hal untuk melakukan kegiatan sesuai tujuannya. 


\begin{abstract}
Motivasi adalah dorongan dasar yang menggerakkan seseorang bertingkah laku. Etos belajar santri akan meningkat jika ada motivasi dari berbagai pihak, diantarnya motivasi dari orang tua. Dorongan ini berada pada diri seseorang yang menggerakkan untuk melakukan sesuatu yang sesuai dengan dorongan dalam dirinya. Oleh karena itu, perbuatan seseorang yang didasarkan atas motivasi tertentu mengandung tema sesuai dengan motivasi yang mendasarinya. Motivasi adalah kekuatan, baik dari dalam maupun dari luar yang mendorong seseorang untuk mencapai tujuan tertentu yang telah ditetapkan sebelumnya (Uno, 2011: 1).
\end{abstract}

Etos belajar merupakan sikap atau perilaku yang tumbuh dalam melakukan pembelajaran, karena adanya dorongan energi positif dari orang tuanya, hal tersebut dipengaruhi faktor internal dan eksternal. faktor internal adalah faktorfaktor yang berasal dari dalam diri individu dan dapat memengaruhi etos belajar individu. Motivasi orang tua sebagai faktor internal dapat memepengaruhi etos belajar santri Faktor-faktor internal ini meliputi faktor fisiologis dan faktor psikologis. Faktor fisiologis adalah faktor-faktor yang berhubungan dengan kondisi fisik individu. Sedangkan faktor Psikologis adalah keadaan psikologis seseorang yang dapat mempengaruhi proses belajar. Beberapa faktor psikologis yang utama mempengaruhi proses belajar adalah kecerdasan siswa, motivasi, minat, sikap dan bakat. Motivasi adalah salah satu faktor yang mempengaruhi keefektifan belajar siswa. Motivasilah yang mendorong siswa ingin melakukan kegiatan belajar.

Motivasi orang tua dapat mempengaruhi keberhasilan proses belajar santri dalam mengembangkan bakat yang dimiliki anaknya. Bakat secara umum, bakat (aptitude) didefinisikan sebagai kemampuan potensial yang dimiliki seseorang untuk mencapai keberhasilan pada masa yang akan datang (Syah, 2013: 132-134).

3. Teori antar kepemimpinan kharismatik kyai dan motivasi orang tua dengan etos belajar santri

Sebagaimana telah di sampaiakn di atas bahwa pemimpin kharismatik esensinya adalah pemimpin transpormasi. Dalam teori Weber, kepemimpinan seperti ini menggunakan pesona / daya tarik pribadi dan kharisma dalam menjalankan roda kepemimpinannya untuk membantu mereka dalam mencapai tujuannya (Danim, 2010: 93). Oleh karena itu, pada perkembangan berikutnya, kepemimpinan transformasional memiliki idealisasi pengaruh (Idealized Influence).

Dalam teori Mc. Donald dalam Sardiman, bahwa motivasi adalah perubahan energi dalam diri seseorang yang ditandai dengan munculnya "feeling" dan didahului dengan tanggapan terhadap adanya tujuan (Sardiman, 2016: 73).Motivasi ialah proses yang menjelaskan intensitas, arah, dan ketekunan seseorang guna mencapai tujuannya (Mitchell, 1997: 60-62). Tiga elemen utama dalam definisi ini diantaranya adalah intensitas, arah, dan ketekunan (Robbins, 2008: 222-232).Dalam kegiatan belajar mengajar, apabila ada siswa yang tidak berbuat sesuatu yang seharusnya mereka lakukan, maka perlu adnya penelitian penyebab hal tersebut. Hal itu berarti pada diri anak tersebut tidak terdapat energi positif / dorongan untuk memiliki etos belajar yang baik.

Kepemimpinan kharismatik seorang kyai dan motivasi orang tua dapat memberikan dorongan dasar kepada santri dalam etos belajar (bertingkah laku sehari-hari ) Oleh karena itu, kepemimpinan kharismatik kyai dan motivasi oarng tua memiliki 
idealisasi pengaruh (Idealized Influence) terhadap etos belajar santri. Idealisasi pengaruh adalah perilaku yang menghasilkan standar perilaku yang tinggi, memberikan wawasan dan kesadaran akan visi, menunjukkan keyakinan, menimbulkan rasa hormat, bangga dan percaya, menumbuhkan komitmen dan unjuk kerja melebihi ekspektasi, dan menegakkan perilaku moral yang etis (Avolio, Bass, Jung, 1999: 441-462).

Secara logika bahwa Santri sebagai bawahan dari kyai dan orang tuanya. santri ketika di didalam lembaga pondok pesantren sebagai bawahan kyai akan senantiasa menunjukan prilaku yang dipengaruhi oleh kyai sebagai pemimpin yang punya Pengaruh kharismatik didalam kehidupan lingkungan pesantren. santri ketika di dirumah sebagai bawahan orang tua akan senantiasa menunjukan prilaku yang dipengaruhi oleh orang tua sebagai orang yang memberikan motivasi didalam kehidupan lingkungan rumah. Santri selalu belajar dari ekspresi yang terpancar dari kharismatik kyai, santri senantiasa memiliki etos belajar dari pengaruh motivasi orang tua yang merangsang pada dirinya untuk belajar. Belajar adalah tingkah laku yang dihasilkan dari rangsangan (Mustakim, 2012: 33).

Dengan demikian kepemimpinan kharismatik kyai dan motivasi orang tua dapat merangsang dan mempengaruhi etos belajar santri dalam aktivitas sehari-hari di pesantren. Pengaruh kharismatik dan Motivasilah yang mendorong siswa ingin melakukan kegiatan belajar.

Motivasi orang tua dapat mempengaruhi keberhasilan proses belajar santri dalam mengembangkan bakat yang dimiliki anaknya. Bakat secara umum, bakat (aptitude) didefinisikan sebagai kemampuan potensial yang dimiliki seseorang untuk mencapai keberhasilan pada masa yang akan datang (Syah, 2013: 132-134).

\section{B. Metode Penelitian}

Penelitian ini menggunakan pendekatan kuantitatif yang bersifat korelasional dalam rangka mengetahui hubungan setiap variabel penelitian dengan menggunakan teknik analisis regresi untuk mengetahui besarnya pengaruh antar variabel. Penelitian kuantitatif adalah “ pendekatan penelitian yang banyak dituntut menggunakan angka, mulai dari pengumpulan data, penafsiran terhadap data tersebut, serta penampilan hasilnya (Arikunto, 2010: 12).

1. Tempat dan Waktu Penelitian

Tempat Penelitian ini dilakukan di Pondok Pesantren 'Ainurrafiq Jl. Pemuda No. 001 RT 007 RW 003, Desa Panawuan, Kecamatan Cigandamekar, Kabupaten Kuningan, Jawa Barat. Adapun waktu yang digunakan untuk penelitian ini yaitu terhitung tanggal 27 Mei 2018 sampai 30Agustus 2018.

Pendekatan penelitian ini adalah kuantitatif korelasional untuk mengetahui hubungan setiap variabel penelitian dengan menggunakan teknik analisis regresi untuk mengetahui besarnya pengaruh antar variabel. Model antar hubungan antar variabel kepemimpinan kharismatik kyai (x1) dan motivasi orang tua (x2) terhadap etos belajar santri (Y) sebagai berikut:

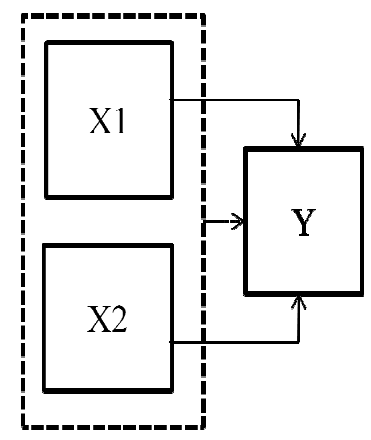

Gambar 1. Skema Paradigma Penelitian

Asep Kurniawan Vol. 2 No.2 ISSN 2549-0877 
Adapun metode dalam penelitian ini, langkah pertama mengumpulkan data yang terkempul selama penelitian dianalisis guna menjawan permasalahan yang sudah diajukan sebelumnya. Angket yang dirancang dalam 30 pertanyaan untuk para santri Pesantren 'Ainurrafiq Kuningan. Setiap item ditentukan dengan skor 1-3 dengan katagori yang telah ditetapkan peneliti, yaitu untuk pilihan (a) bobot nilai3, pilihan (b) bobot nilai 2, dan pilihan (c) bobot nilainya 1. Adapun sekor 3 menunjukkan katagori baik, skor 2 menunjukkan katagori cukup, skor 1 menunjukkan katagori kurang.

2. Populasi dan Sampel

Populasi penelitian ini adalah seluruh santri dan kiai Pondok Pesantren 'Ainurrafiq. Populasi penelitian ini berjumlah 156 orang, terdiri daro seorang pemimpin pesantren, 5 guru dan 150 santri.

Dalam menentukan jumlah sampel jika subyek kurang dari 100, lebih baik diambil semua sehingga penelitiannya merupakan penelitian populasi. Selanjutnya kalau subyeknya lebih besar bisa diambil antara $10-15 \%$ atau $20-25 \%$ atau lebih. Sehingga penelitiannya disebut penelitian sampling (Arikunto, 2010: 115-117). Pada penelitian ini diambil sampelnya sebanyak 29 orang, terdiri dari 29 orang santri $(18,58 \%)$ dari jumlah populasi.

3. Instrumen Penelitian

\section{a. Angket}

Dalam penelitian ini digunakan angket tertutup, sehingga responden cukup menjawab pertanyaanpertanyaan yang telah disediakan. Tujuan kuesioner di sini digunakan sebagai metode pokok dalam memperoleh data.

Skala pengukuran yang digunakan dalam angket ini menggunakan skala Likert. Skala ini berfungsi untuk mengukur sikap, pendapat dan persepsi seseorang atau kelompok orang tentang fenomena sosial (Sugiono, 2016: 134). Dalam penelitian sosial ini telah ditetapkan secara spesifik oleh peneliti, yang selanjutnya disebut variabel penelitian. Adapun variabel yang akan diukur dijabarkan menjadi indikator sebagai titi tolak untuk menyusun item instrumen berupa pertanyaan. Jawaban dari pertanyaan-pertanyaan tersebut ada tiga pilihan, yaitu kata ya (diberi skor 3), kadang-kadang (diberi skor 2) dan tidak (diberi skor 1).

b. Dokumentasi

Dokumenatasi dalam penelitian ini digunakan sebagai bukti telah melakukan penelitian di lokasi tersebut (berupa photo) dan sebagai pendukung memperkuat data yang diperoleh dengan cara mengambil hal yang berkaitan dengan data penelitian yang ada di Pondok Pesantren 'Ainurrafiq Kuningan, serta mendapatkan gambaran keadaan lokasi dan sarana prasara yang ada di Pondok Pesantren 'Ainurrafiq Kuningan.

c. Observasi

Observasi dalam penelitian ini digunakan sebagai bahan tambahan memperkuat data yang diperoleh melalui angket dengan mengumpulkan keterangan dari beberpa responden atau santri yang ada di Pondok Pesantren 'Ainurrafiq Kuningan.

Intrumen penelitian sebelum digunakan dilakukan pengujian terlebih dahulu dari sisi validitas dan reliabilitasnya.

\section{Analisis Data}

Data dicari skor tertinggi dan terendah kemudia dicari intervalnya dengan rumus:

$$
i=\frac{(\mathrm{xt}-\mathrm{xr})+1}{k i}
$$


Keterangan:

$\mathrm{i} \quad=$ interval

$\mathrm{xt}=$ nilai tertinggi

$\mathrm{xr} \quad=$ nilai terendah

$\mathrm{ki}=$ kelas interval (tinggi, sedang, rendah)

Kemudian dicari prosentase kepemimpinan kharismatik kiai dengan rumus:

$$
P=\frac{F}{N} \times 100 \%
$$

5. Rancangan Uji Hipotesis

Kepemimpinan kharismatik (x1) dan motivasi orang tua $(\mathrm{x} 2)$ terhadap etos belajar santri $(\mathrm{Y})$ dalam penelitian ini menggunakan komputerisasi program SPSS 17.0 for windows. Hal ini ditampilkan dalam bentuk skor, ratarata/meas, median, modus, standar deviasi/simpangan baku, niali terendah, nilai maksimum.

\section{Temuan Penelitian}

1. Pengaruh kepemimpinan kharismatik kyai terhadap etos belajar santri

Data nilai tentang pengaruh kepemimpinan kharismatik kyai terhadap etos belajar santru di pondok pesantren 'Ainurrafiq Kuningan sebagaimana terlihat dari hasil angket di bawah ini.

Tabel 12

Distribusi Nilai Hasil Angket

Tentang Kepemimpinan Kharismatik Kyai Terhadap Etos Belajar Santri

\begin{tabular}{|c|c|c|c|c|c|c|c|c|c|c|c|c|c|}
\hline \multirow{2}{*}{$\begin{array}{c}\text { No. } \\
\text { Responden }\end{array}$} & \multicolumn{10}{|c|}{ Nomor item dan skor } & $\begin{array}{c}\text { Skor } \\
\text { Total }\end{array}$ \\
\cline { 2 - 17 } & $\mathbf{1}$ & $\mathbf{2}$ & $\mathbf{3}$ & $\mathbf{4}$ & $\mathbf{5}$ & $\mathbf{6}$ & $\mathbf{7}$ & $\mathbf{8}$ & $\mathbf{9}$ & $\mathbf{1 0}$ & $\mathbf{1 1}$ & $\mathbf{1 2}$ & \\
\hline 1 & 2 & 2 & 2 & 3 & 3 & 3 & 3 & 3 & 3 & 3 & 3 & 3 & 33 \\
\hline 2 & 2 & 2 & 2 & 3 & 3 & 3 & 3 & 3 & 3 & 2 & 3 & 3 & 32 \\
\hline 3 & 2 & 2 & 2 & 3 & 3 & 2 & 3 & 2 & 3 & 2 & 3 & 3 & 30 \\
\hline 4 & 2 & 2 & 3 & 3 & 3 & 2 & 3 & 3 & 3 & 3 & 3 & 3 & 33 \\
\hline 5 & 2 & 3 & 2 & 3 & 3 & 2 & 3 & 3 & 3 & 3 & 3 & 3 & 33 \\
\hline 6 & 2 & 2 & 3 & 3 & 3 & 3 & 3 & 3 & 3 & 3 & 3 & 3 & 34 \\
\hline 7 & 2 & 2 & 2 & 2 & 2 & 2 & 2 & 2 & 2 & 2 & 2 & 2 & 24 \\
\hline 8 & 2 & 3 & 2 & 3 & 3 & 2 & 2 & 3 & 3 & 3 & 3 & 3 & 32 \\
\hline 9 & 2 & 2 & 2 & 2 & 2 & 2 & 2 & 2 & 2 & 2 & 2 & 2 & 24 \\
\hline 10 & 2 & 2 & 2 & 2 & 3 & 2 & 2 & 3 & 2 & 2 & 3 & 3 & 28 \\
\hline 11 & 2 & 3 & 2 & 2 & 3 & 3 & 3 & 3 & 3 & 3 & 3 & 3 & 33 \\
\hline 12 & 3 & 3 & 3 & 3 & 3 & 3 & 3 & 3 & 3 & 3 & 3 & 3 & 36 \\
\hline 13 & 2 & 2 & 2 & 3 & 3 & 2 & 3 & 3 & 2 & 2 & 3 & 3 & 30 \\
\hline 14 & 2 & 2 & 2 & 2 & 3 & 2 & 3 & 3 & 3 & 2 & 3 & 3 & 30 \\
\hline 15 & 2 & 3 & 3 & 3 & 3 & 3 & 3 & 3 & 3 & 3 & 1 & 3 & 33 \\
\hline 16 & 3 & 3 & 3 & 3 & 3 & 3 & 3 & 3 & 3 & 3 & 3 & 3 & 36 \\
\hline 17 & 2 & 2 & 3 & 3 & 3 & 3 & 3 & 3 & 3 & 3 & 3 & 3 & 34 \\
\hline 18 & 2 & 2 & 3 & 3 & 3 & 3 & 3 & 3 & 3 & 2 & 3 & 3 & 33 \\
\hline 19 & 2 & 2 & 3 & 3 & 3 & 3 & 2 & 3 & 3 & 3 & 3 & 3 & 33 \\
\hline 20 & 2 & 2 & 2 & 3 & 3 & 3 & 3 & 3 & 2 & 2 & 3 & 2 & 30 \\
\hline 21 & 2 & 2 & 3 & 2 & 3 & 3 & 3 & 3 & 3 & 3 & 3 & 3 & 33 \\
\hline 22 & 2 & 2 & 2 & 2 & 3 & 3 & 2 & 3 & 3 & 2 & 3 & 3 & 30 \\
\hline 23 & 2 & 2 & 2 & 3 & 3 & 2 & 3 & 3 & 2 & 2 & 3 & 3 & 30 \\
\hline 24 & 2 & 2 & 2 & 3 & 3 & 2 & 3 & 3 & 3 & 3 & 3 & 3 & 32 \\
\hline 25 & 2 & 2 & 2 & 2 & 3 & 3 & 3 & 3 & 3 & 3 & 2 & 3 & 31 \\
\hline 26 & 2 & 2 & 2 & 3 & 3 & 2 & 3 & 3 & 3 & 2 & 2 & 3 & 30 \\
\hline 27 & 2 & 2 & 2 & 3 & 3 & 2 & 3 & 3 & 3 & 3 & 3 & 3 & 32 \\
\hline 28 & 2 & 2 & 3 & 3 & 3 & 3 & 3 & 3 & 2 & 0 & 3 & 3 & 30 \\
\hline 29 & 3 & 3 & 2 & 3 & 3 & 3 & 3 & 3 & 3 & 2 & 3 & 3 & 34 \\
\hline & & & & & & & & \\
\hline
\end{tabular}


Berdasarkan data tabel di atas dapat kami jelaskan sebagai berikut:

a. Dari soal angket nomor 1 yang selalu mengagumi kepada pak kyai sebanyak 3 orang responden (menjawab A) dan sebanyak 26 orang responden menjawab kadang-kadang (menjawab B) dan tidak ada seorang pun yang menjawab tidak mengagumi (menjawab C).

b. Dari soal angket nomor 2 yang selalu menunduk atau membungkuk jika bertemu pak kyai sebanyak 6 orang responden (menjawab A) dan sebanyak 23 orang responden menjawab kadangkadang (menjawab B) dan tidak ada seorang pun yang memilih pilihan $\mathrm{C}$.

c. Dari soal angket nomor 3 yang selalu tertarik ingin mengikuti pak kyai yang pandai menguasai kitab kuning sebanyak 10 orang responden (menjawab A) dan sebanyak 19 orang responden menjawab kadang-kadang (menjawab B) dan tidak ada seorang pun yang memilih pilihan $\mathrm{C}$.

d. Dari soal angket nomor 4 yang tertarik ingin selalu mengetahui semua hal dikuasai pak kyai sebanyak 21 orang responden (menjawab A) dan sebanyak 8 orang responden menjawab kadangkadang (menjawab B ) dan tidak ada seorang pun yang memilih pilihan $\mathrm{C}$.

e. Dari soal angket nomor 5 yang selalu melaksanakan arahan pak kyai sebanyak 27 orang responden yang menjawab selalu menunduk jika ketemu pak kyai (menjawab A) dan sebanyak 2 orang responden menjawab kadangkadang (menjawab B ) dan tidak ada seorang pun yang memilih pilihan $\mathrm{C}$.

f. Dari soal angket nomor 6 yang selalu menekuni pelajaran yang disampaiakn pak kyai sebanyak 16 orang responden (menjawab A) dan sebanyak 13 orang responden menjawab kadang-kadang (menjawab B) dan tidak ada seorang pun yang memilih pilihan $\mathrm{C}$. g. Dari soal angket nomor 7 yang selalu merasa ada perubahan sikap lebih dewasa setelah mendapat bimbingan pak kyai sebanyak 23 orang responden (menjawab A) dan sebanyak 6 orang responden menjawab kadang-kadang (menjawab B) dan tidak ada seorang pun yang memilih pilihan $\mathrm{C}$.

h. Dari soal angket nomor 8 yang selalu mengikuti pola hidup pak kyai yang kharismatik sebanyak 23 orang responden (menjawab A) dan sebanyak 6 orang responden menjawab kadangkadang (menjawab B) dan tidak ada seorang pun yang memilih pilihan $\mathrm{C}$.

i. Dari soal angket nomor 9 yang selalu merasa membekas dalam disiplin belajar dari pengaruh wibawa pak kyai sebanyak 22 orang responden (menjawab A) dan sebanyak 7 orang responden menjawab kadang-kadang (menjawab B) dan tidak ada seorang pun yang memilih pilihan $C$.

j. Dari soal angket nomor 10 yang selalu merasa malu oleh pak kyai jika melakukan pelanggaran, sebanyak 15 orang responden (menjawab A) dan sebanyak 13 orang responden menjawab kadang-kadang (menjawab B) dan ada seorang yang tidak memberikan jawaban (nilai pilihan 0).

k. Dari soal angket nomor 11 yang selalu merasakan kehadiran pak kyai ketika melakukan pelanggaran sebanyak 24 orang responden (menjawab A) dan sebanyak 4 orang responden menjawab kadang-kadang (menjawab B) dan ada 1 orang yang memilih pilihan $\mathrm{C}$.

1. Dari soal angket nomor 6 yang selalu meniru pak kyai rajin beribadah sebanyak 26 orang responden (menjawab A ) dan sebanyak 3 orang responden menjawab kadang-kadang (menjawab B) dan tidak ada seorang pun yang memilih pilihan $\mathrm{C}$ 
Tabel 13

Distribusi Frekuensi Jawaban Tentang Pengaruh Kepeimpinan Kharismatik Kyai Terhadap Etos Belajar Santri

\begin{tabular}{|c|c|c|c|c|c|}
\hline \multirow{2}{*}{$\begin{array}{c}\text { No. } \\
\text { Res }\end{array}$} & \multicolumn{3}{|c|}{ Alternatif Jawaban } & \multirow{2}{*}{ Total } & \multirow{2}{*}{ Nominal } \\
\cline { 2 - 4 } A & 27 & B & C & & \\
\hline 2. & 24 & 8 & 0 & 33 & B \\
\hline 3. & 18 & 12 & 0 & 32 & B \\
\hline 4. & 27 & 6 & 0 & 33 & B \\
\hline 5. & 27 & 6 & 0 & 33 & B \\
\hline 6. & 30 & 4 & 0 & 34 & A \\
\hline 7. & 0 & 24 & 0 & 24 & C \\
\hline 8. & 24 & 8 & 0 & 32 & B \\
\hline 9. & 0 & 24 & 0 & 24 & C \\
\hline 10. & 12 & 16 & 0 & 28 & C \\
\hline 11. & 27 & 6 & 0 & 33 & B \\
\hline 12. & 36 & 0 & 0 & 36 & A \\
\hline 13. & 18 & 12 & 0 & 30 & B \\
\hline 14. & 18 & 12 & 0 & 30 & B \\
\hline 15. & 30 & 2 & 0 & 33 & B \\
\hline 16. & 36 & 0 & 0 & 36 & A \\
\hline 17. & 30 & 4 & 0 & 34 & A \\
\hline 18. & 27 & 6 & 0 & 33 & B \\
\hline 19. & 27 & 6 & 0 & 33 & B \\
\hline 20. & 18 & 12 & 0 & 30 & B \\
\hline 21. & 27 & 6 & 0 & 33 & B \\
\hline 22. & 18 & 12 & 0 & 30 & B \\
\hline 23. & 18 & 12 & 0 & 30 & B \\
\hline 24. & 24 & 8 & 0 & 32 & B \\
\hline 25. & 21 & 10 & 0 & 31 & B \\
\hline 26. & 18 & 12 & 0 & 30 & B \\
\hline 27. & 24 & 8 & 0 & 32 & B \\
\hline 28. & 24 & 6 & 0 & 30 & B \\
\hline 29. & 30 & 4 & 0 & 34 & A \\
\hline
\end{tabular}

Dari data di atas dapat dicari skor tertinggi dan terendah, kemudian dicari intervalnya dengan menggunakan rumus:

$$
i=\frac{(\mathrm{xt}-\mathrm{xr})+1}{k i}
$$

Keterangan:

$$
\begin{array}{ll}
\mathrm{i} & =\text { interval } \\
\mathrm{xt} & =\text { nilai tertinggi } \\
\mathrm{xr} & =\text { nilai terendah } \\
\mathrm{ki} & =\text { kelas interval (tinggi, } \\
\text { sedang, rendah) }
\end{array}
$$

Maka berdasarkan tabel di atas tersebut dapat diketahui pada variable pengaruh kepemimpinan kharismatik kyai terhadap etos belajar santri di Pondok Pesantren 'Ainurrafiq Kuningan, nilai tertinggi 36 dan nilai terendah 24. Dalam hal ini dapat dihitung dengan rumus sebagai berikut:

$$
\begin{aligned}
& i=\frac{(\mathrm{xt}-\mathrm{xr})+1}{k i} \\
& i=\frac{13}{3}=4,3
\end{aligned}
$$

Jadi jelas bahwa pada variabel ini dapat dikategorikan variasi tinggi, sedang, rendah sebagai berikut:

a. Untuk kategori tinggi dengan jawaban A mendapat nilai 34-36

b. Untuk kategori sedang dengan jawaban B mendapat nilai 29-33

c. Untuk kategori rendah dengan jawaban C mendapat nilai 24-28Kemudian dicari prosentase frekuensi pengaruh kepemimpinan kharismatik kyai terhadap etos belajar santri di pondok pesantren 'Ainurrafiq Kuningan dengan rumus:

$$
P=\frac{F}{N} \times 100 \%
$$

a. Untuk pengaruh kepemimpinan kharismatik kyai terhadap etos belajar santri di pondok pesantren 'Ainurrafiq Kuningan yang tinggi, antara skor 34-36 sebanyak 5 santri:

$$
\begin{gathered}
P=\frac{F}{N} \times 100 \% \\
P=\frac{5}{29} \times 100 \%=17,24 \%
\end{gathered}
$$

b. Untuk pengaruh kepemimpinan kharismatik kyai terhadap etos belajar santri di pondok pesantren 'Ainurrafiq Kuningan yang sedang, antara skor 29-33 sebanyak 21 santri:

$$
\begin{aligned}
& P=\frac{F}{N} \times 100 \% \\
& P=\frac{21}{29} \times 100 \%=72,41 \%
\end{aligned}
$$

Asep Kurniawan Vol. 2 No.2 ISSN 2549-0877 
c. Untuk pengaruh kepemimpinan kharismatik kyai terhadap etos belajar santri di pondok pesantren 'Ainurrafiq Kuningan yang rendah, antara skor 24-28 sebanyak 2 santri:

$$
P=\frac{F}{N} \times 100 \%
$$

$$
P=\frac{3}{29} \times 100 \%=10,34 \%
$$

Untuk lebih jelasnya penulis sampaikan dalam bentuk tabel distribusi frekuensi tentang pengaruh kepemimpian kharismatik kyai terhadap etos belajar santri.

Tabel 14

Hasil Distribusi Frekuensi Tentang

Pengaruh Kepemimpinan Kharismatik Kyai Terhadap Etos Belajar Santri

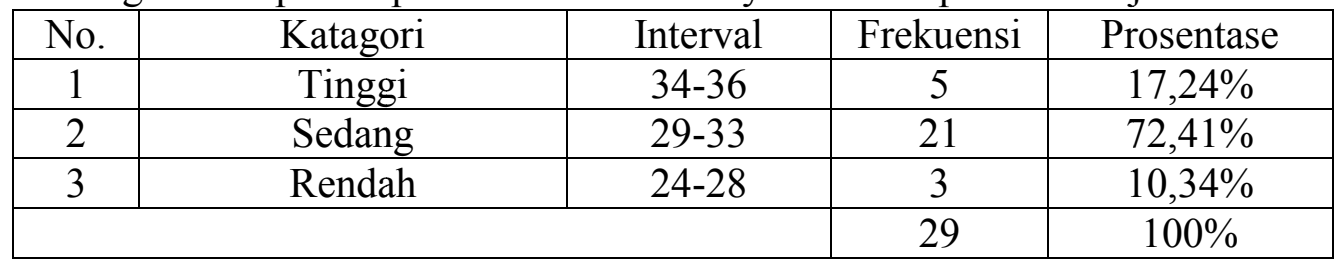

Sumber : hasil pengolahan jawaban angket

Distribusi frekuensi di atas menunjukkan bahwa frekuensi data pengaruh kepemimpinan kharismatik kyai terhadap etos belajar santri, tertinggi pada kategori sedang, yaitu sebanyak 21 jawaban responden dari 29 santri sebagai responden. Karena nilai rata-rata jawaban responden berada pada interval 29-33, hal ini menunjukkan bahwa pengaruh kepemimpinan kharismatik kyai terhadap etos belajar santri di Pondok
Pesantren 'Ainurrafiq Kuningan berada pada kategori sedang, yakni $72,41 \%$.

2. Pengaruh motivasi orang tua terhadap etos belajar santri

Data nilai angket tentang pengaruh motivasi orang tua terhadap etos belajar santri di Pondok Pesantren 'Ainurrafiq Kuningan sebagaimana terlihat dari hasil angket di bawah ini.

Tabel 15

Distribusi Nilai Hasil Angket Tentang

Motivasi Orang TuaTerhadap Etos Belajar Santri

\begin{tabular}{|c|c|c|c|c|c|c|c|c|c|c|c|}
\hline \multirow{2}{*}{$\begin{array}{c}\text { No. } \\
\text { Responden }\end{array}$} & \multicolumn{10}{|c|}{$\begin{array}{c}\text { Skor } \\
\text { Total }\end{array}$} \\
\hline & $\mathbf{1}$ & $\mathbf{2}$ & $\mathbf{3}$ & $\mathbf{4}$ & $\mathbf{5}$ & $\mathbf{6}$ & $\mathbf{7}$ & $\mathbf{8}$ & $\mathbf{9}$ & $\mathbf{1 0}$ & 24 \\
\hline 1 & 2 & 3 & 3 & 3 & 3 & 3 & 1 & 1 & 2 & 3 & 24 \\
\hline 2 & 3 & 3 & 3 & 3 & 2 & 3 & 2 & 3 & 3 & 2 & 27 \\
\hline 3 & 3 & 3 & 3 & 3 & 3 & 3 & 3 & 3 & 3 & 2 & 29 \\
\hline 4 & 3 & 3 & 3 & 3 & 3 & 3 & 2 & 2 & 2 & 3 & 27 \\
\hline 5 & 2 & 3 & 3 & 3 & 2 & 3 & 2 & 2 & 3 & 3 & 26 \\
\hline 6 & 3 & 3 & 3 & 3 & 3 & 3 & 3 & 2 & 3 & 3 & 29 \\
\hline 7 & 2 & 2 & 2 & 2 & 2 & 2 & 2 & 2 & 2 & 2 & 20 \\
\hline 8 & 2 & 3 & 3 & 3 & 3 & 3 & 2 & 2 & 3 & 3 & 27 \\
\hline 9 & 2 & 2 & 2 & 2 & 2 & 2 & 2 & 2 & 2 & 2 & 20 \\
\hline 10 & 3 & 3 & 3 & 3 & 3 & 2 & 1 & 1 & 3 & 3 & 25 \\
\hline 11 & 2 & 3 & 3 & 3 & 2 & 3 & 3 & 3 & 3 & 3 & 28 \\
\hline 12 & 2 & 3 & 3 & 3 & 2 & 3 & 3 & 3 & 3 & 3 & 28 \\
\hline 13 & 3 & 3 & 3 & 3 & 3 & 3 & 2 & 2 & 2 & 3 & 27 \\
\hline
\end{tabular}




\begin{tabular}{|l|l|l|l|l|l|l|l|l|l|l|l|}
\hline 14 & 2 & 3 & 3 & 3 & 3 & 2 & 2 & 2 & 3 & 3 & 26 \\
\hline 15 & 3 & 3 & 3 & 3 & 2 & 3 & 2 & 3 & 3 & 3 & 28 \\
\hline 16 & 2 & 3 & 2 & 3 & 3 & 3 & 3 & 3 & 3 & 3 & 28 \\
\hline 17 & 3 & 3 & 3 & 3 & 3 & 3 & 3 & 3 & 3 & 3 & 30 \\
\hline 18 & 3 & 3 & 3 & 3 & 3 & 3 & 2 & 2 & 3 & 3 & 28 \\
\hline 19 & 3 & 3 & 3 & 3 & 3 & 3 & 2 & 3 & 3 & 3 & 29 \\
\hline 20 & 3 & 3 & 2 & 3 & 2 & 3 & 2 & 2 & 3 & 3 & 26 \\
\hline 21 & 3 & 3 & 3 & 3 & 3 & 3 & 2 & 3 & 3 & 3 & 29 \\
\hline 22 & 2 & 3 & 3 & 3 & 2 & 3 & 2 & 2 & 3 & 3 & 26 \\
\hline 23 & 2 & 3 & 3 & 3 & 3 & 2 & 1 & 2 & 3 & 3 & 25 \\
\hline 24 & 3 & 3 & 3 & 3 & 3 & 3 & 2 & 1 & 3 & 3 & 27 \\
\hline 25 & 3 & 3 & 3 & 3 & 3 & 3 & 1 & 2 & 2 & 3 & 26 \\
\hline 26 & 2 & 3 & 3 & 3 & 2 & 2 & 3 & 2 & 2 & 3 & 25 \\
\hline 27 & 3 & 3 & 3 & 3 & 2 & 3 & 3 & 3 & 1 & 3 & 27 \\
\hline 28 & 2 & 3 & 3 & 3 & 2 & 3 & 2 & 3 & 3 & 2 & 26 \\
\hline 29 & 3 & 3 & 2 & 3 & 2 & 3 & 3 & 2 & 3 & 3 & 27 \\
\hline
\end{tabular}

Berdasarkan data tabel di atas dapat kami jelaskan sebagai berikut:

a. Dari soal angket nomor 1 yang menjawab selalu merasa bertambah wawasan pendidikan agama Islam berkat orang tua memasukan ke pesantren, sebanyak 16 orang responden (menjawab A) dan sebanyak 13 orang responden menjawab kadangkadang (menjawab B) dan tidak ada seorang pun yang menjawab tidak merasa bertambah wawasan agama islam di pesantren (menjawab C).

b. Dari soal angket nomor 2 yang menjawab selalu mendapat perhatian orang tua dengan menanyakan perkembangan belajarnya di pesantren, sebanyak 27 orang responden (menjawab A) dan sebanyak 2 orang responden menjawab kadang-kadang (menjawab B ) dan tidak ada seorang pun yang menjawab tidak pernah (menjawab C).

c. Dari soal angket nomor 3 yang menjawab selalu didampingi orang tua ketika di rumah pada saat mendapat kesulitan dalam pelajaran, sebanyak 24 orang responden ( menjawab A) dan sebanyak 5 orang responden menjawab kadang-kadang (menjawab B) dan tidak ada seorang pun yang menjawab tidak pernah (menjawab C).

d. Dari soal angket nomor 4 yang menjawab selalu mendapat bantuan orang tua ketika melakukan indisipliner di pesantren, sebanyak 27 orang responden ( menjawab A) dan sebanyak 2 orang responden menjawab kadangkadang (menjawab B) dan tidak ada seorang pun yang menjawab tidak pernah (menjawab C).

e. Dari soal angket nomor 5 yang menjawab selalu dipenuhi semua kebutuhannya di pesantren, sebanyak 16 orang responden (menjawab A) dan sebanyak 13 orang responden menjawab kadang-kadang (menjawab B) dan tidak ada seorang pun yang menjawab tidak pernah (menjawab $\mathrm{C}$ ).

f. Dari soal angket nomor 6 yang menjawab selalu mendapat nasehat orang tua agar rajin belajar di pesantren, sebanyak 23 orang responden (menjawab A) dan sebanyak 6 orang responden menjawab kadang-kadang (menjawab B) dan tidak ada seorang pun yang menjawab tidak pernah (menjawab C).

g. Dari soal angket nomor 7 yang menjawab selalu dinasehati orang tua ketika melakukan kesalahan, sebanyak 9 orang responden (menjawab A) dan sebanyak 16 orang responden menjawab kadang-kadang (menjawab B) dan ada 4 orang responden yang menjawab tidak pernah (menjawab $\mathrm{C}$ ).

h. Dari soal angket nomor 8 yang menjawab selalu mendapat motivasi Asep Kurniawan Vol. 2 No.2 ISSN 2549-0877 
orang tua agar semangat dalam belajar, sebanyak 11 orang responden (menjawab A) dan sebanyak 15 orang responden menjawab kadang-kadang (menjawab B) dan ada 3 orang responden yang menjawab tidak pernah (menjawab C).

i. Dari soal angket nomor 9 yang menjawab sering mendapat motivasi dan semangat dari orang tua dalam belajar di pesantren tentang manfaat memiliki ilmu agama islam untuk kehidupan masa depan, sebanyak 21 orang responden (menjawab A) dan sebanyak 7 orang responden menjawab kadang-kadang (menjawab B) dan ada 1 orang yang menjawab tidak pernah (menjawab C).

j. Dari soal angket nomor 2 yang menjawab selalu mendapatkan hadiah dari orang tua ketika mendapat penghargaan dari pesantren, sebanyak 24 orang responden (menjawab A) dan sebanyak 5 orang responden menjawab kadang-kadang (menjawab B) dan tidak ada seorang pun yang menjawab tidak pernah (menjawab C).

Tabel 16

Distribusi Frekuensi Jawaban Tentang Pengaruh Motivasi Orang Tua Terhadap Etos Belajar Santri

\begin{tabular}{|c|c|c|c|c|c|}
\hline \multirow{2}{*}{$\begin{array}{c}\text { No. } \\
\text { Responden }\end{array}$} & \multicolumn{3}{|c|}{ Alternatif Jawaban } & \multirow[t]{2}{*}{ Total } & \multirow[t]{2}{*}{ Nominasi } \\
\hline & $\mathbf{A}$ & B & $\mathbf{C}$ & & \\
\hline 1 & 18 & 4 & 2 & 24 & $\mathrm{C}$ \\
\hline 2 & 21 & 6 & 0 & 27 & $\mathrm{~B}$ \\
\hline 3 & 27 & 2 & 0 & 29 & $\mathrm{~B}$ \\
\hline 4 & 21 & 6 & 0 & 27 & B \\
\hline 5 & 18 & 8 & 0 & 26 & $\mathrm{~B}$ \\
\hline 6 & 27 & 2 & 0 & 29 & $\mathrm{~B}$ \\
\hline 7 & 0 & 20 & 0 & 20 & $\mathrm{C}$ \\
\hline 8 & 21 & 6 & 0 & 27 & $\mathrm{~B}$ \\
\hline 9 & 0 & 20 & 0 & 20 & $\mathrm{~B}$ \\
\hline 10 & 21 & 2 & 0 & 25 & $\mathrm{~B}$ \\
\hline 11 & 24 & 4 & 0 & 28 & $\mathrm{~B}$ \\
\hline 12 & 24 & 4 & 0 & 28 & $\mathrm{~B}$ \\
\hline 13 & 21 & 6 & 0 & 27 & $\mathrm{~B}$ \\
\hline 14 & 18 & 8 & 0 & 26 & B \\
\hline 15 & 24 & 4 & 0 & 28 & B \\
\hline 16 & 24 & 4 & 0 & 28 & B \\
\hline 17 & 30 & 0 & 0 & 30 & A \\
\hline 18 & 24 & 4 & 0 & 28 & B \\
\hline 19 & 27 & 2 & 0 & 29 & B \\
\hline 20 & 18 & 8 & 0 & 26 & B \\
\hline 21 & 27 & 2 & 0 & 29 & B \\
\hline 22 & 18 & 8 & 0 & 26 & B \\
\hline 23 & 18 & 6 & 1 & 25 & B \\
\hline 24 & 24 & 2 & 1 & 27 & B \\
\hline 25 & 21 & 4 & 1 & 26 & B \\
\hline 26 & 15 & 10 & 0 & 25 & B \\
\hline 27 & 24 & 2 & 1 & 27 & B \\
\hline 28 & 18 & 8 & 0 & 26 & B \\
\hline 29 & 21 & 6 & 0 & 27 & B \\
\hline
\end{tabular}


Dari data di atas dapat dicari skor tertinggi dan terendah, kemudian dicari intervalnya dengan menggunakan rumus:

$$
i=\frac{(\mathrm{xt}-\mathrm{xr})+1}{k i}
$$

Keterangan :

$\mathrm{i}=$ interval

$\mathrm{xt}=$ nilai tertinggi

$\mathrm{xr}=$ nilai terendah

$\mathrm{ki}=$ kelas interval (tinggi, sedang, rendah)

Maka berdasarkan tabel di atas tersebut dapat diketahui pada variabel pengaruh motivasi orang tua terhadap etos belajar santri, nilai tertinggi 30 dan nilai terendah 20. Dalam hal ini dapat dihitung dengan rumus sebagai berikut:

$$
\begin{gathered}
i=\frac{(x t-x r)+1}{k i} \\
i=\frac{(30-20)+1}{3} \\
i=\frac{11}{3}=3,66=4
\end{gathered}
$$

Jadi jelas bahwa pada variabel ini dapat dikategorikan variasi tinggi, sedang, rendah sebagai berikut:

a. Untuk kategori tinggi dengan jawaban A mendapat nilai 30.

b. Untuk kategori sedang dengan jawaban B mendapat nilai 25-29.

c. Untuk kategori rendah dengan jawaban C mendapat nilai 20-24
Kemudian dicari prosentase pengaruh motivasi orang tua terhadap etos belajar santri dengan rumus

$$
P=\frac{F}{N} \times 100 \%
$$

a. Untuk pengaruh motivasi orang tua terhadap etos belajar santri, yang tinggi pada skor 30 sebanyak 1 santri:

$$
\begin{aligned}
& P=\frac{F}{N} \times 100 \% \\
& P=\frac{1}{29} \times 100 \%=3,44 \%
\end{aligned}
$$

b. Untuk pengaruh motivasi orang tua terhadap etos belajar santri, yang sedang antara skor 25-29 sebanyak 25 santri:

$$
\begin{aligned}
& P=\frac{F}{N} \times 100 \% \\
& P=\frac{25}{29} \times 100 \%=86,20 \%
\end{aligned}
$$

c. Untuk pengaruh motivasi orang tua terhadap etos belajar santri, yang rendah antara skor 20-24 sebanyak 3 santri:

$$
\begin{aligned}
& P=\frac{F}{N} \times 100 \% \\
& P=\frac{3}{29} \times 100 \%=10,34 \%
\end{aligned}
$$

Untuk lebih jelasnya penulis sampaikan dalam bentuk tabel distribusi frekuensi pengaruh motivasi orang tua terhadap etos belajar santri.

Tabel 17

Hasil Distribusi Frekuensi Tentang

Pengaruh Motivasi Orang TuaTerhadap Etos Belajar Santri

\begin{tabular}{|c|c|c|c|c|}
\hline No. & Motivasi Orang Tua & Interval & Frekuensi & Prosentase \\
\hline 1 & Tinggi & 30 & 1 & $3,44 \%$ \\
\hline 2 & Sedang & $25-29$ & 25 & $86,20 \%$ \\
\hline 3 & Rendah & $20-24$ & 3 & $10,34 \%$ \\
\hline & & & 29 & $100 \%$ \\
\hline
\end{tabular}

Sumber : hasil pengolahan jawaban angket

Distribusi frekuensi di atas menunjukkan bahwa pengaruh motivasi orang tua terhadap etos belajar santri tertinggi pada kategori sedang, yaitu 
sebanyak 25 jawaban responden dari 29 santri sebagai responden. Karena nilai rata-rata jawaban responden berada pada interval 25-29, hal ini menunjukkan bahwa pengaruh motivasi orang tua terhadap etos belajar santri di Pondok Pesantren 'Ainurrafiq Kuningan berada pada kategori sedang, yakni sebanyak $86,20 \%$.
3. Pengaruh kepemimpinan kharismatik kyai dan motivasi orang tua terhadap etos belajar santri

Data nilai angket tentang pengaruh kepemimpinan kharismatik kyai dan motivasi orang tua terhadap etos belajar santri di Pondok Pesantren 'Ainurrafiq Kuningan sebagaimana terlihat dari hasil angket di bawah ini.

Tabel 18

Distribusi Nilai Hasil Angket Tentang Kepemimpinan Kharismatik Kyai

Dan Motivasi Orang Tua Terhadap Etos Belajar Santri

\begin{tabular}{|c|c|c|c|c|c|c|c|c|c|}
\hline \multirow{2}{*}{$\begin{array}{c}\text { No. } \\
\text { Responden }\end{array}$} & \multicolumn{8}{|c|}{ Nomor item dan skor } & \multirow{2}{*}{$\begin{array}{l}\text { Skor } \\
\text { Tota }\end{array}$} \\
\hline & 1 & 2 & 3 & 4 & 5 & 6 & 7 & 8 & \\
\hline 1 & 3 & 3 & 3 & 2 & 2 & 3 & 2 & 2 & 20 \\
\hline 2 & 3 & 3 & 3 & 3 & 3 & 3 & 3 & 3 & 24 \\
\hline 3 & 2 & 2 & 3 & 3 & 3 & 3 & 3 & 3 & 22 \\
\hline 4 & 3 & 3 & 3 & 3 & 3 & 3 & 2 & 3 & 23 \\
\hline 5 & 2 & 2 & 2 & 2 & 2 & 2 & 2 & 2 & 16 \\
\hline 6 & 3 & 2 & 2 & 3 & 2 & 3 & 2 & 3 & 20 \\
\hline 7 & 2 & 2 & 2 & 2 & 3 & 3 & 3 & 3 & 20 \\
\hline 8 & 2 & 2 & 3 & 3 & 3 & 3 & 2 & 2 & 20 \\
\hline 9 & 2 & 2 & 2 & 2 & 2 & 2 & 2 & 2 & 16 \\
\hline 10 & 2 & 2 & 2 & 3 & 3 & 3 & 3 & 3 & 21 \\
\hline 11 & 3 & 3 & 3 & 3 & 3 & 3 & 2 & 3 & 23 \\
\hline 12 & 2 & 2 & 2 & 2 & 2 & 3 & 3 & 2 & 18 \\
\hline 13 & 3 & 2 & 2 & 2 & 2 & 3 & 3 & 3 & 20 \\
\hline 14 & 3 & 2 & 3 & 2 & 2 & 3 & 3 & 2 & 20 \\
\hline 15 & 3 & 2 & 3 & 3 & 3 & 2 & 2 & 3 & 21 \\
\hline 16 & 2 & 2 & 2 & 2 & 2 & 3 & 3 & 3 & 19 \\
\hline 17 & 2 & 2 & 3 & 2 & 2 & 2 & 3 & 2 & 18 \\
\hline 18 & 3 & 2 & 2 & 3 & 2 & 2 & 3 & 3 & 20 \\
\hline 19 & 3 & 3 & 2 & 3 & 3 & 3 & 3 & 3 & 23 \\
\hline 20 & 2 & 3 & 3 & 3 & 3 & 2 & 3 & 3 & 22 \\
\hline 21 & 3 & 2 & 2 & 3 & 2 & 3 & 3 & 2 & 20 \\
\hline 22 & 3 & 3 & 3 & 3 & 3 & 3 & 3 & 3 & 24 \\
\hline 23 & 3 & 2 & 2 & 3 & 3 & 2 & 2 & 3 & 20 \\
\hline 24 & 3 & 2 & 3 & 3 & 3 & 3 & 2 & 3 & 22 \\
\hline 25 & 3 & 2 & 3 & 2 & 2 & 2 & 2 & 2 & 18 \\
\hline 26 & 2 & 3 & 3 & 2 & 3 & 2 & 2 & 2 & 19 \\
\hline 27 & 3 & 3 & 3 & 3 & 3 & 1 & 2 & 2 & 20 \\
\hline 28 & 3 & 2 & 3 & 3 & 2 & 3 & 3 & 3 & 22 \\
\hline 29 & 3 & 2 & 2 & 3 & 2 & 2 & 2 & 3 & 19 \\
\hline
\end{tabular}


Berdasarkan data tabel di atas dapat kami jelaskan sebagai berikut:

a. Dari soal angket nomor 1 yang menjawab selalu mengikuti pengajian sesuai jadwal pelajaran sebanyak 18 orang responden (menjawab A) dan sebanyak 11 orang responden menjawab kadang-kadang (menjawab B) dan tidak ada seorang pun yang menjawab tidak pernah (menjawab C).

b. Dari soal angket nomor 2 yang menjawab selalu mengajak teman satu kamar / kobong berangkat bersamasama setiap jadwal pengajian sebanyak 9 orang responden (menjawab A) dan sebanyak 20 orang responden menjawab kadang-kadang (menjawab B) dan tidak ada seorang pun yang menjawab tidak pernah (menjawab C)

c. Dari soal angket nomor 3 yang menjawab selalu tepat waktu dalam mengikuti pelajaran sebanyak 16 orang responden (menjawab A) dan sebanyak 13 orang responden menjawab kadangkadang (menjawab B) dan tidak ada seorang pun yang menjawab tidak pernah ( menjawab C)

d. Dari soal angket nomor 4 yang menjawab selalu awal waktu dalam sholat pardu dan sholat jumat sebanyak 18 orang responden (menjawab A) dan sebanyak 11 orang responden menjawab kadang-kadang (menjawab B) dan tidak ada seorang pun yang menjawab tidak pernah (menjawab C).

e. Dari soal angket nomor 5 yang menjawab selalu semangat dalam belajar ketika didalam kelas sebanyak 15 orang responden (menjawab A) dan sebanyak 14 orang responden menjawab kadang-kadang (menjawab B) dan tidak ada seorang pun yang menjawab tidak pernah (menjawab C).

f. Dari soal angket nomor 6 yang menjawab selalu belajar kitab kuning meskipun diluar kelas sebanyak 18 orang responden (menjawab A) dan sebanyak 10 orang responden menjawab kadang-kadang (menjawab B) dan ada 1 orang responden yang menjawab tidak pernah (menjawab C).

g. Dari soal angket nomor 7 yang menjawab selalu bertanya kepada teman atau kepada pak kyai ketika ada pelajaran yang belum difahami sebanyak 15 orang responden (menjawab A) dan sebanyak 14 orang responden menjawab kadang-kadang (menjawab B) dan tidak ada seorang pun yang menjawab tidak pernah (menjawab C).

h. Dari soal angket nomor 8 yang menjawab selalu tetap belajar didalam kelas sampai jam pelajaran habis ketika pak kyai berhalangan hadir mengajar sebanyak 18 orang responden (menjawab A) dan sebanyak 11 orang responden menjawab kadang-kadang (menjawab B) dan tidak ada seorang pun yang menjawab tidak pernah (menjawab C).

Tabel 19

Distribusi Frekuensi Jawaban Tentang

Pengaruh Kepemimpinan Kharismatik Kyai

Dan Motivasi Orang Tua Terhadap Etos Belajar Santri

\begin{tabular}{|c|c|c|c|c|c|}
\hline \multirow{2}{*}{ No. Responden } & \multicolumn{3}{|c|}{ Alternatif Jawaban } & \multirow{2}{*}{ Total } & \multirow{2}{*}{ Nominasi } \\
\cline { 2 - 4 } & A & B & C & & \\
\hline 1 & 12 & 8 & 0 & 20 & B \\
\hline 2 & 24 & 0 & 0 & 24 & A \\
\hline 3 & 18 & 4 & 0 & 22 & B \\
\hline 4 & 21 & 2 & 0 & 23 & B \\
\hline 5 & 0 & 16 & 0 & 16 & C \\
\hline 6 & 12 & 8 & 0 & 20 & B \\
\hline 7 & 12 & 8 & 0 & 20 & B \\
\hline
\end{tabular}




\begin{tabular}{|c|c|c|c|c|c|}
\hline 8 & 12 & 8 & 0 & 20 & $\mathrm{~B}$ \\
\hline 9 & 0 & 16 & 0 & 16 & $\mathrm{C}$ \\
\hline 10 & 15 & 6 & 0 & 21 & $\mathrm{~B}$ \\
\hline 11 & 21 & 2 & 0 & 23 & $\mathrm{~B}$ \\
\hline 12 & 6 & 12 & 0 & 18 & $\mathrm{C}$ \\
\hline 13 & 12 & 8 & 0 & 20 & $\mathrm{~B}$ \\
\hline 14 & 12 & 8 & 0 & 20 & $\mathrm{~B}$ \\
\hline 15 & 15 & 6 & 0 & 21 & $\mathrm{~B}$ \\
\hline 16 & 9 & 10 & 0 & 19 & $\mathrm{C}$ \\
\hline 17 & 6 & 12 & 0 & 18 & $\mathrm{C}$ \\
\hline 18 & 12 & 8 & 0 & 20 & $\mathrm{~B}$ \\
\hline 19 & 21 & 2 & 0 & 23 & $\mathrm{~B}$ \\
\hline 20 & 18 & 4 & 0 & 22 & $\mathrm{~B}$ \\
\hline 21 & 12 & 8 & 0 & 20 & $\mathrm{~B}$ \\
\hline 22 & 24 & 0 & 0 & 24 & $\mathrm{~A}$ \\
\hline 23 & 12 & 8 & 0 & 20 & $\mathrm{~B}$ \\
\hline 24 & 18 & 4 & 0 & 22 & $\mathrm{~B}$ \\
\hline 25 & 6 & 12 & 0 & 18 & $\mathrm{C}$ \\
\hline 26 & 9 & 10 & 0 & 19 & $\mathrm{C}$ \\
\hline 27 & 15 & 4 & 0 & 20 & $\mathrm{~B}$ \\
\hline 28 & 18 & 4 & 0 & 22 & $\mathrm{~B}$ \\
\hline 29 & 9 & 10 & 0 & 19 & $\mathrm{C}$ \\
\hline
\end{tabular}

Dari data di atas dapat dicari skor tertinggi dan terendah, kemudian dicari intervalnya dengan menggunakan rumus:

$$
i=\frac{(x t-x r)+1}{k i}
$$

Keterangan:

$\mathrm{i} \quad=$ interval

$\mathrm{xt}=$ nilai tertinggi

$\mathrm{xr} \quad=$ nilai terendah

ki = kelas interval (tinggi, sedang, rendah)

Maka berdasarkan tabel di atas tersebut dapat diketahui pada variabel pengaruh kepemimpinan kharismatik kyai dan motivasi orang tua terhadap etos belajar santri Ponpes 'Ainurrafiq Kuningan, nilai tertinggi 24 dan nilai terendah 16. Dalam hal ini dapat dihitung dengan rumus sebagai berikut:

$$
\begin{aligned}
& i=\frac{(x t-x r)+1}{k i} \\
& i=\frac{(24-16)+1}{3} \\
& i=\frac{9}{3}=3
\end{aligned}
$$

Jadi jelas bahwa pada variabel ini dapat dikategorikan variasi tinggi, sedang, rendah sebagai berikut :

a. Untuk kategori tinggi dengan jawaban A mendapat nilai 24

b. Untuk kategori sedang dengan jawaban B mendapat nilai 20-23

c. Untuk kategori rendah dengan jawaban C mendapat nilai $16-19$

Kemudian dicari prosentase frekuensi Y dengan rumus

$$
P=\frac{F}{N} \times 100 \%
$$

a. Untuk pengaruh kepemimpinan kharismatik kyai dan motivasi orang tua terhadap etos belajar santri yang tinggi, pada skor 24 sebanyak 2 santri:

$$
P=\frac{2}{29}=\times 100 \%=6,89 \%
$$

b. Untuk pengaruh kepemimpinan kharismatik kyai dan motivasi orang tua terhadap etos belajar santri yang sedang, antara skor 20-23 sebanyak 19 santri:

$$
P=\frac{19}{29}=\times 100 \%=65,51 \%
$$

Asep Kurniawan Vol. 2 No.2 ISSN 2549-0877 
c. Untuk pengaruh kepemimpinan kharismatik kyai dan motivasi orang tua terhadap etos belajar santri yang rendah, antara skor 16-19 sebanyak 8 santri :

$$
P=\frac{8}{29}=\times 100 \%=27,58 \%
$$

Untuk lebih jelasnya penulis sampaikan dalam bentuk tabel distribusi frekuensi pengaruh kepemimpinan kharismatik kyai dan motivasi orang tua terhadap etos belajar santri.

Tabel 20

Hasil Distribusi Frekuensi Jawaban Tentang Pengaruh Kepemimpinan Kharismatik Kyai Dan Motivasi Orang

Tua Terhadap Etos Belajar Santri

\begin{tabular}{|c|c|c|c|c|}
\hline ?a & 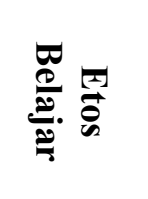 & $\begin{array}{l}\overline{0} \\
\frac{0}{2} \\
\triangleq\end{array}$ & 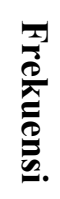 & 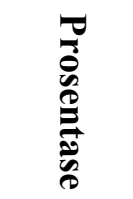 \\
\hline 1 & Tinggi & 24 & 2 & $6,89 \%$ \\
\hline 2 & Sedang & $20-23$ & 19 & $65,51 \%$ \\
\hline 3 & Rendah & $16-19$ & 8 & 27,585 \\
\hline \multicolumn{3}{|c|}{ Jumlah } & 29 & $100 \%$ \\
\hline
\end{tabular}

Sumber: hasil pengolahan jawaban angket

Berdasarkan deskripsi di atas, bahwa pengaruh kepemimpinan kharismatik kyai dan motivasi orang tua terhadap etos belajar santri menunjukkan bahwa jumlah responden terbanyak yaitu pada frekuensi 19 pada kategori sedang berada pada interval 20-23 hal ini menunjukkan bahwa pengaruh kepemimpinan kharismatik kyai dan motivasi orang tua terhadap etos belajar santri di Ponpes 'Ainurrafiq Kuningan berada pada kategori sedang yakni dengan nilai prosentase sebesar $65,51 \%$.

\section{Pembahasan}

Teori yang mendasarai penelitian ini bahwa pengaruh gaya kepemimpinan dan motivasi kerja berpengaruh positif dan signifikan terahadap kinerja guru.1 Teori tersebut telah dilakukan oleh Yeni Absah dengan judul tesis Pengaruh Gaya Kepemimpinan dan Motivasi Kerja Terhadap Kinerja Guru di SMPN 1 Pandan Kabupaten Tapanuli Tengah (2014), Abdulkadir Mohamud Dahie, Mohamed Omar Mohamed, dan Mohamed Mire Jim'ale dengan judul Leadership Style and Teacher Work Motivation Empiricirical Investigation from Secondary Shools in Mogadishu Somalia(2015), Aunga1, David A. O. dan Obadia Masare1 dengan judul Effect of Leadership Styles on Teacher's Performance in Primary Schools of Arusha District Tanzania (2017) menunjukan bahwa nilai $\mathrm{F}$ hitung sebesar $23,488>$ dari F tabel yaitu 2,6. Sementara tingkat signifikasi $0.000<0,005$. Maka kedua indikator tersebut menunjukan pengaruh gaya kepemimpinan dan motivasi kerja berpengaruh positif dan signifikan terahadap kinerja guru. Penelitian tersebut memiliki persamaan dengan penelitian yang dilakukan peneliti secara teori.

Berdasarkan teori hasil temuan di atas, maka hipotesis positif dugaan atau jawaban sementara pada penelitian ini dapat penulis kemukakan bahwa:

1. Terdapat pengaruh positif kepemimpinan kharismatik kyai terhadap etos belajar santri pada Pondok Pesantren 'Ainurrafiq Kuningan.

2. Terdapat pengaruh positif Motivasi orang tua terhadap etos belajar santri pada Pondok Pesantren 'Ainurrafiq Kuningan.

3. Terdapat pengaruh positif kepemimpinan kharismatik kyai dan motivasi orang tua terhadapetos belajar santri pada Pondok Pesantren 'Ainurrafiq Kuningan.

a. Analisis uji hipotesis kepemimpinan kharismatik kyai terhadap etos belajar santri Pengolahan data tentang kepemimpinan kharismatik kyai (X1) terhadap etos belajar santri (Y) di Ponpes 'Ainurrafiq Kuningandalam penelitian ini menggunakan bantuan komputerisasi 
program SPSS 17.0 for windows. Berikut ini adalah hasil analisis uji hipotesis kepemimpinan kharismatik kyai dengan menggunakan analisis regresi.

Tabel 21

Hasil Analisis Uji Hipotesis Kepemimpinan Kharismatik Kyai Terhadap Etos Belajar Santri

\begin{tabular}{|l|c|c|}
\hline \multicolumn{1}{|c|}{ Uraian } & $\mathrm{X}_{1}$ & Kesimpulan \\
\hline $\mathrm{b}$ (koefisien regresi) & 0,266 & \multirow{2}{*}{ Berpengaruh signifikan } \\
\cline { 1 - 2 } $\mathrm{t}_{\text {hitung }}$ & $2,281^{*}$ & \\
\hline Signifikansi $(P)$ & 0,031 & \\
\hline
\end{tabular}

Keterangan :

$*=$ taraf signifikan $5 \%$.

$\mathrm{P}=$ probabilitas / signifikansi

Apabila angka probabilitas hasil anlisa $<0,05$ maka hipotesis (Ho ) ditolak dan hipotesis kerja ( Hk ) diterima.2 Uji t yang diperoleh dari perhitungan menggunakan program SPSS 17.0 for windows yaitu nilai thitung sebesar 2,281 dan probabilitas sebesar 0,031<0,05 maka Ho ditolak yang berarti ada pengaruh yang positif dan signifikan variabel kepemimpinan kharismatik kyai terhadap etos belajar santri di Ponpes 'Ainurrafiq Kuningan.

Kepemimpinan kharismatik kyai mempunyai pengaruh yang signifikan terhadap etos belajar santri. Hal ini dibuktikan dengan perolehan hasil uji $\mathrm{t}$ dengan nilai probabilitas sebesar $0,031<0,05$.

Artinya semakin tinggi pengaruh kepemimpinan kharismatik kyai maka akan semakin tinggi pula etos belajar santri. Kharismatik kyai tersebut akan memberikan dampak besar pada semangat santri dalam belajar di pondok pesantren. Oleh sebab itu kharismatik kyai berpengaruh terhadap etos belajar santri dalam segala aktivitas santri di pondok pesantren.

b. Analisis uji hipotesis motivasi orang tua terhadap etos belajar santri Hasil analisis motivasi orang tua dengan menggunakan analisis regresi disajikan dalam tabel berikut.

Tabel 22

Hasil Analisis Uji Hipotesis Motivasi Orang Tua

Terhadap Etos Belajar Santri

\begin{tabular}{|l|c|c|}
\hline \multicolumn{1}{|c|}{ Uraian } & $\mathrm{X}_{1}$ & Kesimpulan \\
\hline $\mathrm{b}$ (koefisien regresi) & 0,659 & \multirow{2}{*}{ Berpengaruh signifikan } \\
\cline { 1 - 2 } $\mathrm{t}_{\text {hitung }}$ & $7,658^{*}$ & \\
\hline Signifikansi $(P)$ & 0,000 & \\
\hline
\end{tabular}

Keterangan :

$*=$ taraf signifikan 5\%.

$\mathrm{P}=$ probabilitas / signifikansi

Apabila angka probabilitas hasil anlisa $<0,05$ maka hipotesis (Ho ) ditolak dan hipotesis kerja
(Hk) diterima.3 Pada uji t diperoleh nilai thitung sebesar 7,658 dan probabilitas sebesar $0,000<0,05$ 
maka Ho ditolak yang berarti ada kontribusi yang positif dan signifikan variabel motivasi orang tua terhadap etos belajar santri Ponpes 'Ainurrafiq Kuningan.

Hasil uji hipotesis membuktikan bahwa terdapat kontribusi positif dan signifikan motivasi orang tua terhadap etos belajar santri. Hal ini ditunjukkan dengan perolehan hasil uji $t$ dengan nilai probabilitas sebesar 0,000 $<0,05$. Artinya, motivasi orang tua mempunyai pengaruh yang signifikan terhadap etos belajar santri.

c. Analisis uji hipotesis kepemimpinan kharismatik kyai dan motivasi orang tua terhadap etos belajar santri Berdasrkan uraian di atas, berikut ini kami sajikan hasil analisis uji pengaruh kepemimpinan kharismatik kyai dan motivasi orang tua terhadap etos belajar santri di Pondok Pesantren 'Ainurrafiq Kuningan

Tabel 23

Hasil Analisis Uji Hipotesis Kepemimpinan Kharismatik Kyai Dan Motivasi Orang Tua Terhadap Etos Belajar Santri

\begin{tabular}{|l|c|c|}
\hline \multicolumn{1}{|c|}{ Uraian } & $\mathrm{X}_{1}$ & Kesimpulan \\
\hline $\mathrm{b}$ (koefisien regresi) & 0,378 & \multirow{2}{*}{ Berpengaruh signifikan } \\
\cline { 1 - 2 } Signifikansi $(P)$ & 0,016 & \\
\hline $\mathrm{F}$ & $32,511^{*}$ & \\
\hline $\mathrm{R}^{2}$ & 0,714 & \\
\hline
\end{tabular}

Keterangan :

$*=$ taraf signifikan $5 \%$

$\mathrm{P}=$ probabilitas / signifikansi

Hasil analisis uji hipotesis pengaruh kepemimpinan kharismatik kyai dan motivasi orang tua secara bersama-sama terhadap etos belajar santri dengan menggunakan program SPSS 16.0 for windows menunjukan hasil pada tabel uji F, hasil uji Anova atau $\mathrm{F}$ test. Pada penelitian ini di dapat nilai Fhitung adalah 32,511 dengan tingkat signifikansi 0,016 . Nilai probabilitas $0,016>0,05$ maka hipotesis Ho ditolak yang berarti kepemimpinan kharismatik kyai dan motivasi orang tua secara simultan memiliki kontribusi signifikan dan positif terhadap etos belajar santri.

\section{E. Keterbatasan Penelitian}

Penelitian ini terbatas hanya di pesantren 'Ainurrafiq Kuningan pada tiga variabel saja, yaitu kepemimpinan kharismatik kyai, motivasi orang tua dan etos belajar santi. Berdasarkan hasil uji analisis di atas, Untuk mengetahui besarnya pengaruh kepemimpinan kharismatik kyai dan motivasi orang tua terhadap etos belajar santri dapat diukur dengan nilai koefisien determinasi (R2) yang bermakna besarnya sumbangan variabel bebas $(\mathrm{X})$ terhadap variabel terikat (Y). berdasarkan hasil pengujian regresi linear berganda diperoleh nilai R2 (R Square) sebesar 0,714 yang berarti besarnya kontribusi variabel $\mathrm{X}$ (independent) terhadap Y (dependent) sebesar $71,4 \%$ sedangkan sisanya sebesar $29,6 \%$ disumbangkan oleh faktor-faktor lain yang tidak dijelaskan dalam penelitian ini.

Hal tersebut ditunjukkan dengan perolehan hasil uji $F$ dengan nilai probabilitas sebesar $0,016<0,05$. Apabila kepemimpinan kharismatik kyai besar maka etos belajar santri akan semakin meningkat. Demikian pula dengan motivasi orang tua apabila santri Asep Kurniawan Vol. 2 No.2 ISSN 2549-0877 
mendapatkan motivasi dan dorongan yang besar dari orang tuanya, maka para santri akan mempunyai etos belajar yang tinggi pula.

Berdasarkan hasil analisis hasil uji hipotesis di atas membuktikan bahwa terdapat kontribusi positif dan signifikan kepemimpinan kharismatik kyai dan motivasi orang tua terhadap etos belajar santri di pondok pesantren 'Ainurrafiq Kuningan.

\section{F. Penutup}

Berdasarkan hasil penelitian di pondok pesantren 'Ainurrafiq Kuningan ini, dapat kami simpulkan sebagai berikut:

1. Kepemimpinan kharismatik kyai mempunyai pengaruh yang signifikan terhadap etos belajar santri. Apabila angka probabilitas hasil anlisa $<0,05$ maka hipotesis (Ho) ditolak dan hipotesis kerja (Hk) diterima. Hal itu terbukti pada Uji t yang diperoleh dari perhitungan menggunakan program SPSS 17.0 for windows yaitu nilai thitung sebesar 2,281 dan probabilitas sebesar $0,031<0,05$ maka Ho ditolak yang berarti ada pengaruh yang positif dan signifikan variabel kepemimpinan kharismatik kyai terhadap etos belajar santri di Ponpes 'Ainurrafiq Kuningan. Hal ini dibuktikan dengan perolehan hasil uji $\mathrm{t}$ dengan nilai probabilitas sebesar $0,031<0,05$. Artinya semakin tinggi pengaruh kepemimpinan kharismatik kyai maka akan semakin tinggi pula etos belajar santri.

2. Motivasi orang tua mempunyai pengaruh yang signifikan terhadap etos belajar santri. Hal itu terbukti Pada uji t diperoleh nilai thitung sebesar 7,658 dan probabilitas sebesar $0,000<0,05$ maka Ho ditolak yang berarti ada kontribusi yang positif dan signifikan variabel motivasi orang tua terhadap etos belajar santri Ponpes 'Ainurrafiq Kuningan. Hasil uji hipotesis membuktikan bahwa terdapat kontribusi positif dan signifikan motivasi orang tua terhadap etos belajar santri. Artinya, motivasi orang tua mempunyai pengaruh yang signifikan terhadap etos belajar santri.

3. Kepemimpinan kharismatik kyai dan motivasi orang tua mempunyai pengaruh yang signifikan terhadap etos belajar santri. Hal ini di buktikan dari hasil pada tabel uji F, hasil uji Anova atau $\mathrm{F}$ test. Pada penelitian ini di dapat nilai Fhitung adalah 32,511 dengan tingkat signifikansi 0,016 . Nilai probabilitas $0,016>0,05$ maka hipotesis Ho ditolak yang berarti kepemimpinan kharismatik kyai dan motivasi orang tua secara simultan memiliki kontribusi signifikan dan positif terhadap etos belajar santri. Artinya, Kepemimpinan kharismatik kyai dan motivasi orang tua mempunyai pengaruh yang signifikan terhadap etos belajar santri.

Sementara itu penelitian ini memiliki impilikasi, yaitu:

1. Semakin besar pengaruh kepemimpinan kharismatik kyai, maka akan semakin tinggi pula etos belajar santri.

2. Semakin besar pengaruh motivasi orang tua, maka akan semakin tinggi pula etos belajar santri

3. Semakin besar pengaruh kepemimpinan kharismatik kyai dan motivasi orang tua, maka akan semakin tinggi pula etos belajar santri

\section{Referensi :}

Absah, Yeni. 2014. "Pengaruh Gaya Kepemimpinan dan Motivasi Kerja Terhadap Kinerja Guru di SMPN 1 Pandan Kabupaten Tapanuli Tengah", dalam Jurnal Bisnis dan Manajemen Eksekutif, Vol. 1 No. 1, 2014.

Adair-Toteff, Christopher. 2005. "Max Weber's Charisma", dalam Journal of Classical Sociology, Vol. 5, No. 2: 189-204.

Arikunto, Suharsimi. 2010. Prosedur Penelitian Suatu Pendekatan Praktek. Jakarta: Rineka Cipta. 
Aunga1, David A. O. dan Obadia Masare1. 2017. "Effect of Leadership Styles on Teacher's Performance in Primary Schools of Arusha District Tanzania", dalam International Journal of Educational Policy Research and Review, Vol.4 (4), pp. 42-52 April, 2017.

Avolio, B.J., B.M. Bass, D.I. Jung. 1999. "Re-Examining the Components of Transformational and Transactional Leadership Using the Multifactor Leadership Questionnaire", dalam Journal of Occupational and Organizational Psychology, 72: 441462.

Balson, Maurice.1996. Menjadi Manusia Yang Baik. Jakarta: Bumi Aksara.

Danim, Sudarwan. 2010. Kepemimpinan Pendidikan. Bandung: Alfabeta.

Dahie, Abdulkadir Mohamud, Mohamed Omar Mohamed, dan Mohamed Mire Jim'ale. 2015."Leadership Style and Teacher Work Motivation Empiricirical Investigation from Secondary Shools in Mogadishu Somalia", dalam International Journal in Management and Social Science. Vol.03 Issue-10 (October, 2015):276-292.

Joosse, Paul. 2014. "Becoming a God: Max Weber and the Social Construction of Charisma", dalam Journal of Classical Sociology, 14 (3): 266-283.
Mitchell, T. R. 1997. Research in Organizational Behavior. Greenwich, CT: JAI Press.

Muhaimin. 2012. Paradigma Pendidikan Islam: Upaya Mengefektifkan Pendidikan Agama di Sekolah. Bandung: Rosada Karya Offset.

Mustakim.2012. Psikologi Pendidikan. Yogyakarta: Pustaka Belajar.

Robbins, Stephen P. dan Timothy A. Judge, 2008. Perilaku Organisasi Buku 1. Jakarta: Salemba Empat.

Ryan, R. M.; Deci, E. L. 2000. "Selfdetermination Theory and the Facilitation of Intrinsic Motivation, Social Development, and WellBeing", dalam American Psychologist. 55 (1): 68-78.

Sardiman. 2016. Interaksi dan Motivasi Belajar Mengajar. Jakarta: PT Raja Grafindo Persada.

Sugiono. 2016. Metode Penelitian Pendidikan. Bandung: Alfabeta.

Syah, Muhibbin. 2013. Psikologi Pendidikan. Bandung: Remaja

Rosdakarya.

Uno, Hamzah B. 2011. Teori Motivasi dan Pengukurannya. Jakarta: Bumi Aksara.

Weber, Max. 1978. "The Types of Legitimate Domination," dalam Economy and Society: 92-94.

Winch, Christopher dan John Gingell. 2008. Philosophy of Education: The Key Concepts. London: Routledge. 